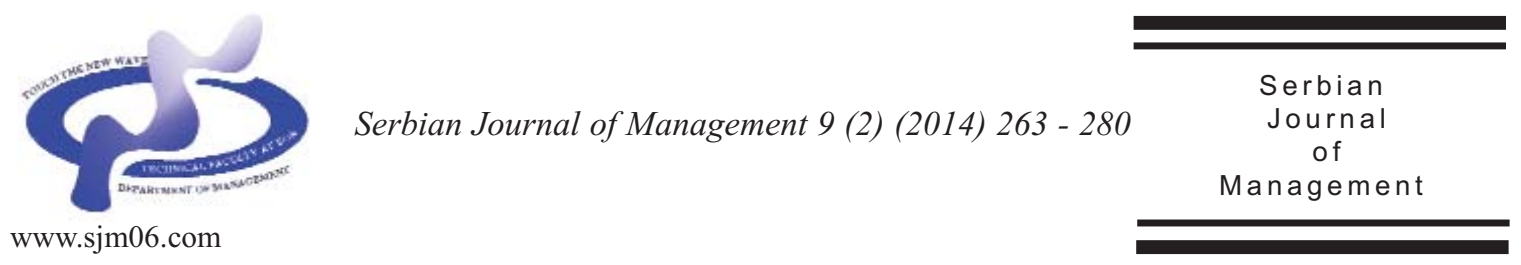

\title{
THE USE OF VOLUNTARY DISCLOSURE IN DETERMINING THE QUALITY OF FINANCIAL STATEMENTS: EVIDENCE FROM THE NIGERIA LISTED COMPANIES
}

\author{
Oyerogba Ezekiel Oluwagbemiga \\ Department of Economics, Accounting and Finance \\ School of Business, Jomo Kenyatta University of Agriculture and Technology \\ P. O. Box 62000-00200, Nairobi, Kenya
}

(Received 23 March 2014; accepted 5 May 2014)

\begin{abstract}
The purpose of this study was to establish the use of voluntary disclosure in determining the quality of financial statements among the listed companies in Nigeria. Specifically the study investigated on the effects of voluntary disclosure on investor decision and performance of listed companies in Nigeria. This study adopted anexploratory design which is described as a method of collecting information by interviewing or administering a questionnaire to a sample of individuals. The instrument of data collection for this research was a questionnaire as the study used primary data. The study targeted all the 258 listed companies in Nigeria. The study population used in this research comprised of preparers (accountants), external auditors and users of accounting information (financial analysts, stockbrokers, bankers, regulators and educators). The sample of this study was 140 whereby twenty questionnaires were distributed in every category of the respondents.Descriptive statistics such as mode, median, mean, standard deviation, etc were used to perform data analysis. These measures were calculated using Statistical Package for the Social Sciences (SPSS 20) software. SPSS tool (Statistical Package for the Social Sciences) was used to organize and analyze data. The study findings indicated that there was increased performance and investor decision making was easy to makedue to voluntary disclosure. The results indicate that voluntary disclosurewas satisfactory in explaining investor decision making and performance of listed companies. It was possible to conclude from the study findings that voluntary disclosure was statistically significant in explaining investor's decision and performance of listed companies in Nigeria. It was also possible to conclude that there was high level of voluntary disclosure in Nigeria listed firms which led to high performance of the firms and made it easy for investors to make decision whether to invest in the companies or not.
\end{abstract}

Keywords: Voluntary disclosure, investor decision, financial statement, performance

\footnotetext{
* Corresponding author: oyeezekiel2903@yahoo.com
}

DOI:10.5937/sjm9-5784 


\section{INTRODUCTION}

The forces that give rise in demand of information disclosure in the modern capital market stems from the information asymmetry and agency conflicts existing between the management and the stockholders. Therefore, the solution to agency conflicts lies in the ownership structure and the function of board of directors. Nowadays, every organization whether it is public or private, big or small, profitable or non profitable is looking forward to satisfy customers, investors, creditors, suppliers, regulators and the public at large. They are trying to operate in a way that makes all those users or stakeholders appreciate them. One way for these organizations to improve their performance is by showing their responsibility toward the environment. There is increasing pressure on companies to be responsible to the society which has influenced them to operate in an environmentally responsible manner. As various stakeholders demand greater disclosure of environmental impacts and performance, a large number of companies all over the world have started reporting on these issues. In many countries, disclosure of some environmental information has also been made mandatory. However, various research findings have suggested that these disclosures vary across sectors, industries and countries (Pahuja, 2009).

Published annual reports are required to provide various users - shareholders, employees, suppliers, creditors, financial analysts, stockbrokers, management, and government agencies - with timely and reliable information useful for making prudent, effective and efficient decisions. The extent and quality of disclosure within these published reports vary from company to company and also from country to country. Literature reveals that the level of reliable and adequate information by listed companies in developing countries lags behind that in developed ones and government regulatory forces are less effective in driving the enforcement of existing accounting standards (Ali et al., 2004). Non-disclosure results from immature development of accounting practice in developing nations (Osisioma, 2001). The government regulatory bodies and the accountancy profession in these nations suffer from structural weaknesses which could encourage corporate fraud at the expense of those that have economic and proprietary interest in the business environment.

In the Nigerian context, comprehensive studies of Nigerian listed companies have been conducted by World Bank Group. It is observed that the Nigerian financial reporting practices are deficient (World Bank, 2004).Apart from the studies conducted by the World Bank, disclosure practices by Nigerian companies have been empirically investigated by Wallace (1988), Okike (2000), Adeyemi (2006), Ofoegbu and Okoye (2006) and Ebiringa and Kule (2014). Their observation is quite similar in that they all found the Nigerian corporate reporting practices to be weak.

Information disclosure of Nigerian firms and the influencing factors has not been sufficiently investigated (Adelopo, 2011). Corporate disclosures can be in two forms: mandatory or voluntary (Hassan \& Marston, 2010; Uyar, 2011). Mandatory disclosures include information that is disclosed based on the expectations of regulatory authority in the country (such as Security and Exchange Commission, Companies and Allied Matters Act). While voluntary disclosures are 
information disclosed based on the firm's free will and decision, which can be financial or non-financial, disclosed over and above the mandatory requirements (Barako et al., 2006). The impact of corporate disclosure on the value of the firm has received diverse attention in extant studies (e.g. Hassan \& Marston, 2010). This is due to the economic consequence of corporate disclosure on the firm. For instance, the cost of corporate disclosure is cheaper compared to cost of less or non-disclosure. This includes cost of law suits that occur when firm information misleads stakeholders. This implies that more attention is needed in the preparation of corporate annual reports.

In Nigeria, the need for better transparency has remained the high priority for policy makers. For instance, the Security and Exchange Commission (2012) noted that some of the standards set up to regulate corporate governance-2003 code of corporate governance, is not sufficient to address the transparency issues of listed firms. This led to the development of other corporate governance code in Nigeria such as the code of Corporate Governance for Public Companies in Nigeria, developed by the 2008 National Committee that was set up by the Securities and Exchange Commission for the review of the 2003 Code of Corporate Governance for Public Companies in Nigeria. Despite these codes, the need to emphasize voluntary disclosure is paramount because firms' being able to disclose information voluntarily will support those requirements mandated by the codes.

\subsection{Statement of the Problem}

The literature on accounting disclosure has investigated a wide range of issues, such as: corporate disclosure practice looking at either obligatory or voluntary items as well as both; determinants of voluntary disclosure or determinants of compliance with regulation; the economic consequences of disclosure; financial analysts" use of information etc. While many disclosure studies have investigated corporate disclosure for private sector companies, others studies have looked at the public sector as well as non-profit organizations. In all these studies, accounting disclosure plays a key role and could be measured in some way. However, disclosure is a theoretical concept, with it being very difficult to measure directly. Thus the literature on disclosure offers a variety of potential proxies that purport to measure disclosure.

The firm's decision to voluntarily disclose information depends on its conjectures about the beliefs held by competitors and investors (Dontoh, 1989). The study of Milgrom (1981) and Grossman (1981) concluded that if the firm can make credible disclosures about its value to uninformed investors, in equilibrium the firm will disclose all of its information regardless of how good or bad the news. Many recent studies have hypothesized that firms' voluntary disclosure choices are aimed at controlling the interest conflicts among shareholders, debt holders, and management (Holthausen \& Leftwich, 1983; Watts \& Zimmerman, 1986). It is meant that the extent of these interest conflicts, hence the incentives behind voluntary disclosure choices vary with certain firm characteristics (Chow \& WongBoren, 1987).

A comprehensive review of the voluntary disclosure literature is provided by Healy and Palepu (2001). They notice that research into voluntary disclosure decision trends focuses on the information role of reporting 
for capital market participants. Indeed, academic researchers, practitioners, and regulators have analyzed and emphasized the role of disclosure plays in reducing information asymmetry between insiders and outsiders (Gandia, 2005). Actually the study of Healy and Palepu (2001) identifies five factors/hypotheses that affect mangers' disclosure decisions for capital market reasons: capital market transaction hypothesis, corporate control contest hypothesis, stock compensation hypothesis, litigation cost hypothesis, and proprietary cost hypothesis. The very abstract way of these hypotheses has been discussed in the study of Collett and Hrasky (2005).

The issue of financial information disclosure by Nigerian quoted companies has been unsatisfactory despite theintroduction of several financial reporting standards over the years. The use of paper-based annual reports as a meansof communicating financial information to shareholders limits the content of needed qualitative informationdisclosed, thus, increasing the risks of companies being undervalued by market. The objective of this paper thereforeis to evaluate the use of voluntary disclosure in determining the quality of financial statements in Nigerian listed firms.

\subsection{Aim and Objectives of the Research}

The primary objective of this research is to evaluate the use of voluntary disclosure in determining the quality of financial statements in Nigerian listed firms. This was achieved by:

I. To investigate the extent to which companies in Nigeria disclose information voluntarily.

II. To establish if voluntary disclosure affects the decision making of investors.
III. To establish if voluntary disclosure affects the performance of the firm.

\subsection{Research Questions}

Supporting the research objectives set out above, the following questions were advanced and answered:

i. To what extent do companies in Nigeria disclose information voluntarily?

ii. Does voluntary disclosure affect the decision making of investors?

iii. What is the effect of voluntary disclosure on the performance of the firm?

\subsection{Research Hypotheses}

\section{Hypothesis One}

Ho1: There is no significant relationship between voluntary disclosure and investor decision making in Nigeria listed firms.

H11: There is significant relationship between voluntary disclosure and investor decision making in Nigeria listed firms.

\section{Hypothesis Two}

Ho2: There is no significant relationship betweenvoluntary disclosure and firm performance in Nigeria listed firms.

H12: There is significant relationship between voluntary disclosure and firm performance in Nigeria listed firms.

Where Ho: is the null hypothesis and HI: is the alternative hypothesis.

\section{SIGNIFICANCE AND THE CONCEPT OF THE STUDY}

This research dwells on the use of voluntary disclosure on the quality of 
financial statements particularly within the context of listed companies in Nigeria. The findings of this research are expected to contribute to existing body of knowledge. Practicing auditors in Nigeria are anticipated to become more informed of the intricacies surrounding voluntary disclosure. The academic community will also benefit enormously from the outcome of this research.

\subsection{Scope and Limitation of the Study}

This research centers on the voluntary disclosure of information within the context of listed companies in Nigeria. This research excludes audits of non listed companies and internal audit function of companies. The outcome of this research is based on what is obtained in Nigeria. It is likely that the opinions expressed may not represent the views of every Nigerian; however these variations are not expected to adversely influence the findings of this research. It identifies the opinion of respondents on disclosure practices of listed Nigerian companies and on consequences of nondisclosure. Due to the nature of research, the respondents are limited to preparers, auditors and knowledgeable users conversant with the disclosure requirements of the accounting standards.

\subsection{Theoretical Framework}

\subsubsection{Voluntary Disclosure Theory}

The notion of voluntary disclosure supports the idea, even in the absence of regulation, managers still wish to disclose additional information. I base this idea on considerations found in agency theory, which assert agency costs are borne mainly by agents (Jensen \& Meckling, 1976). Therefore, agents try to reduce their agency costs to maximize their wealth. As described in agency theory, agency costs are a product of information asymmetry, whereby the agent has more private information about the firm's performance than the principal.

Theoretical and empirical studies in accounting focus on the informational role of voluntary disclosures for the capital markets (e.g., Healy \& Palepu, 2001; Verrecchia, 2001). The SEC and the FASB provide guidelines for mandatory disclosures; the disclosure literature in accounting refers to voluntary and discretionary disclosures, interchangeably, as information management releases itself. The underlying assumption in the disclosure literature is the manager possesses superior information to all outsiders. The result is managers' trade-off between making accounting choices and providing disclosures to "communicate their superior knowledge of a firm's performance to investors, and to manage reported performance for contracting, political, or corporate governance reasons" (Healy \& Palepu, 2001).

Theoretical studies related to disclosure suggest full disclosure of information will occur due to investors' belief non-disclosing firms have the worst possible information (Grossman, 1981). Such studies also assume credible disclosures and zero disclosure costs. However, Verrecchia (1983) suggests, in the presence of fixed, positive disclosure costs, only firms whose information provides economic benefits above such costs will disclose. In addition, disclosure policies are influenced when disclosures provide information to competitors (Verrecchia, 1983). Theoretical studies in accounting related to disclosure are most concerned with what types of disclosures mightoccur, 
instead of disclosures actually made by firms (Healy \& Palepu, 2001).

\subsection{Voluntary Disclosure}

The quality of the annual financial statements of firms in three Continental European countries: Austria, Germany and Switzerland were assessed by Daske and Gebhardt (2006). The period covered was 1998 when the IAS/IFRS standards were revised considerably. The selected firms had already adopted internationally recognized standards (IAS/IFRS or U.S. GAAP) during the period of study. Both univariate and multivariate tests are performed using average, median, mean, t-test, spearman correlation and rank regression. Their multivariate analyses utilize a very similar set of control variables to prior research. These variables are firm size proxied by log of market capitalization or log of total assets, the number of analysts following a firm, its financing needs proxied by leverage, free float, capital intensity and performance measured by return on assets. Their evidence shows that disclosure quality has increased significantly with the adoption of IFRS in the three countries studied, even when controlling firm characteristics.

Iatridis (2008) examines the disclosure of accounting information in the financial statements of UK firms. The study also examines the financial attributes of firms that disclose key accounting issues such as risk exposure, changes in accounting policies, use of international financial reporting standards and hedging practices. Their evidence reveals that firms that provide informative accounting disclosures appear to display higher size, growth, profitability and leverage measures. His findings also reveal that the implementation of international financial reporting standards promotes consistency and reliability of financial reports, enhances the quality and the comparability of financial statements and also facilitates companies raising capital internationally.

In India, Ahmed (2005) investigates the extent of voluntary reporting practices of listed non-financial companies with 12 disclosure items for 100 companies. He also relates the extent of voluntary reporting practices to industry type. An unweighted disclosure index was applied to the corporate annual reports for the year ending between June 30, 2002 and December 31, 2002. He finds that the level of reporting voluntary information items is low and the variability in the level of reporting among the companies is wide. Sector wise comparison of voluntary reporting shows little fluctuations among the sectors that indicate a great deal of similarity among them in respect of reporting voluntary information items.

\subsection{Voluntary Disclosure and Investors Decision Making}

There is a great wealth of disclosure literature that has investigated various determinants of disclosure practice in annual reports in developed capital markets (e.g. Malone et al., 1993; Hossain et al., 1995; Inchausti, 1997). However, a few disclosure studies addressing the extent of voluntary disclosure have been conducted in developing capital markets (e.g. Chow \& Wong-Boren, 1987; Hossain et al., 1994; Ahmed, 1996). In Jordan, Naser et al. (2002) investigate the relationship between 
corporate disclosure after the implementation of International Accounting Standards (IASs) and company's firm characteristics. Using a disclosure index of 86 unweighted items of information, Naser et al. showed that the level of compliance with the IASs is related with corporate liquidity ratio, audit firm status, profitability, gearing, and size. Suwaidan et al. (2004) evaluated the level of social responsibility disclosure practices of 65 industrial Jordanian firms using 37 items of information. The results of the study identified that social disclosure is associated with corporate size, profitability, and risk.

Healy et al. (1999) also used AIMR disclosure rankings and found that the increases in disclosure level are accompanied by increases in firms' stock returns, institutional ownership, analyst following, and stock liquidity. Leuz and Verrecchia (2000) studied German firms that have switched from German GAAP to international accounting regime with a greater disclosure requirement (IAS or USGAAP) in consolidated financial statements. They claimed that these firms were thereby committing themselves to increased levels of disclosure. Leuz and Verrecchia showed that firms adopting international reporting (more disclosure) were associated with lower bidask spreads and higher trading volume than the ones keeping to the German reporting regime. Coller and Yohn (1997) used a sample of 278 quarterly earnings forecast to investigate whether the manager's decision to issue management earnings forecast reduces information asymmetry. They found that forecasting firms have wider bidask spreads than a matched sample of nonforecasting firms prior to the forecast release. Espinosa et al. (2005) examined the relationship between disclosure and liquidity using a sample of Spanish listed firms. They found a positive relationship between disclosure and liquidity using Amihud (2002) illiquidity model.

Lang and Lundholm (2000) examined corporate disclosure activity around seasoned equity offerings and its relationship to stock prices. They found evidence that firms increase their disclosure activity over an extended period of time (six to nine months) in advance of seasoned equity offerings, consistent with managers using disclosure to decrease information asymmetry and increase offering proceeds. Heflin et al. (2002) obtained the measure of a firm's disclosure for 1998 from AIMR and measured the stock market liquidity using two measures of liquidity; bidask spread and depth. They found that a firm with high quality of accounting disclosure enhanced its market liquidity through reducing information asymmetries across traders. Recently, Zhang and Ding (2006) examined the relationship between increased disclosures and bid-ask spread in the Chinese capital market and found that disclosure level is negatively related to bid-ask spread as a measure of stock market liquidity.

\subsection{Voluntary Disclosure and Performance of Firms}

By increasing the quality of accounting information, the likelihood of fraud, distortion and other abuses in the financial statements of these kinds of companies is minimized and presentation of acceptable opinion by independent auditors seems reasonable and logical. Audit privacy led to an increase in auditor change among the companies of the study. In addition with the increase in auditor change, qualified opinion in audit reduces and instead, acceptable 
opinion increases. This suggests that audit privacy, reduces auditor independence and causes the opinion selection phenomenon rise, especially after the organization of the formal accountant's community. Ghasim Osmani and Abbasi (2007) studied the relationship between the cost of capital and the level of financial information disclosure of 87 companies listed in Tehran Stock Exchange. The sample was 87 companies listed in Tehran Stock Exchange. The results showed that there is no significant relationship between the level of information disclosure and cost of capital (cost of equity, cost of debt.)

Arabmazar and Arzitoon (2008) investigated the relationship between financial structure characteristics and corporate performance, and the level of information disclosure in the financial statements of the companies. With a sample of 50 companies listed in Tehran Stock Exchange, they came to the conclusion that: There is a significant relationship between financial structure characteristics and adequate disclosure in the financial statements and there is a significant relationship between corporate performance and adequate disclosure in the financial statements.

The study of Wang et al. (2008) examined empirically the determinants of voluntary disclosure in the annual reports of Chinese listed firms that issue both domestic and foreign shares. The results indicated that the level of voluntary disclosure is positively related to the proportion of state ownership, foreign ownership, firm performance measured by return on equity, and reputation of the engaged auditor. However, there is no evidence, however, that companies benefit from extensive voluntary disclosure by having a lower cost of debt capital. Haniffa and Cooke (2002) examined the relationships between a number of corporate governance, cultural, and firm-specific characteristics, and the extent of voluntary disclosure in the annual reports of a sample of Malaysian companies. A total of 65 items were selected and an unweighted disclosure index was used in the study. The findings indicated a significant association between corporate governance and the extent of voluntary disclosure. In addition, one cultural factor (proportion of Malay directors on the board), was found to be significantly associated with the extent of voluntary disclosure.

\section{METHODOLOGY OF RESEARCH}

This research is based on a survey of all companies operating in Nigeria that are listed on the Nigerian Stock Exchange. The research was designed to capture how selected respondents perceive the use of voluntary disclosure in the financial statements in Nigeria. A pilot study was conducted using five samplesof a questionnaire. This was to ensure the relevancy of the data gathering instrument.The reliability of the data gatheringinstrument was ascertained using a test- retestcorrelation.

The study population used in this researchcomprised of preparers (accountants), external auditors and users of accounting information (financial analysts, stockbrokers, bankers, regulators and educators) on disclosure practices of listed financial and non-financial companies in Nigeria. Theauditors were identified from the Institute of Chartered Accountants of Nigeria (ICAN) website; Stockbrokers were identified on thefloor of the Nigerian Stock 
Exchange, whileindividuals in the capacity of managers werereached, at their different head offices.

Purpose sampling technique was adopted in the selection of respondents required forthis research. This technique was considered suitable because of the emphasis on the knowledge of audit or independence. However, the organizations and individuals used for the research were randomly selected from the strata of seven identified from the study population. Twenty respondents were selected for each of the strata to avoid opinions gathered from being skewed. A total of one forty respondents made up the sample size. Primary data were extensively relied upon in the performance of this research. Questionnaires were used to gather the primary data. Some of the instruments were administered personally while some were forwarded asattachments through emails and returned via the same method.

Primary data was analyzed by use of descriptive statistics and inferential statistics. These measures were calculated using Statistical Package for the Social Sciences (SPSS 20) software. SPSS tool (Statistical Package for the Social Sciences) was used to organize and analyze data. This is because it is user friendly and gives all the possible analysis. The data was presented in form of tables, pie charts, column and bar graphs.

The relationships in the research questions were determined using the following Ordinary Least Squares (OLS) regression model prescribed by Faraway (2002), Cohen et al. (2003). The use of ordinary Least Squares Regression is preferred due to its ability to show whether there is appositive or a negative relationship between independent and dependent variables (Castillo, 2009). In addition, OLS is useful in showing linear elasticity/sensitivity between independent and dependent variables (Cohen et al., 2003). For instance, the current study would like to know the percentage by which responses on voluntary disclosure increases or decreases when responses on quality of financial statements change by 1 percent. Furthermore, OLS was useful in showing whether the identified linear relationship is significant or not.

$\mathrm{Y}_{1}=a_{1}+\beta_{1}(\mathrm{VD})+\varepsilon$

$\mathrm{Y}_{2}=a_{2}+\beta_{2}(\mathrm{VD})+\varepsilon$

Where:

$\mathrm{VD}=$ Voluntary Disclosure

$\mathrm{Y}_{1}=$ Investor Decision

$\mathrm{Y}_{2}=$ Performance

In the model $a_{i}, \mathrm{i}=1 \ldots .2=$ the constant term while the coefficient $\beta_{i}, \mathrm{i}=1 \ldots .2$ was used to measure the sensitivity of the dependent variables $\left(Y_{1} \& Y_{2}\right)$ to unit change in the explanatory variable (VD); $\varepsilon$ is the error term which captures the unexplained variations in the model.

\section{RESULTS AND FINDINGS}

\subsection{Descriptive Results}

This study sought to establish the extent to which companies in Nigeria disclose information voluntarily. The study findings in Table 1 indicated that there was high disclosure of information voluntarily by the listed companies in Nigeria. This was evidenced by a mean score of 4.328 which 
indicates that majority of the respondents agreed that the companies disclosed the Value added statements, Human resource performance, Corporate social responsibility report, Environmental reports, operational information such as internal control systems, company's mission statement, organizational structure/chart and market share analysis.

The study findings are consistent with those of Iatridis (2008) who examined the disclosure of accounting information in the financial statements of UK firms. The study also examined the financial attributes of firms that disclose key accounting issues such as risk exposure, changes in accounting policies, use of international financial reporting standards and hedging practices. Their evidence revealed that firms that provide informative accounting disclosures appear to display higher size, growth, profitability and leverage measures. His findings also revealed that the implementation of international financial reporting standards promotes consistency and reliability of financial reports, enhances the quality and the comparability of financial statements and also facilitates companies raising capital internationally.

The study sought to find out the effect of voluntary disclosure and investor decision making in Nigeria listed firms. Table 2 indicates that voluntary disclosure influences the investor's decision makingin listed companies as was evidenced by a mean score of 4.280. This further implies that majority of the respondents agreed that voluntary disclosure in form of value added statements had made them to invest more in the company, voluntary disclosure in form of $\mathrm{Hr}$ performance has been useful in helping to gauge the sustainability of human resources in the company and voluntary disclosure in form of CSR reports had been useful in helping to gauge the sustainability of company activities. The respondents further agreed that voluntary disclosure in form of environmental reports had been useful in helping to gauge the sustainability of company activities and voluntary disclosure

\section{Table 1. Voluntary Disclosure}

\begin{tabular}{|c|c|c|c|c|}
\hline Statement & Minimum & Maximum & Mean & $\begin{array}{c}\text { Std. } \\
\text { Deviation }\end{array}$ \\
\hline The company discloses the Value added statements & 1 & 5 & 4.39 & 0.826 \\
\hline $\begin{array}{l}\text { The company discloses the Human resource } \\
\text { performance }\end{array}$ & 2 & 5 & 4.45 & 0.73 \\
\hline $\begin{array}{l}\text { The company discloses the Corporate social } \\
\text { responsibility report }\end{array}$ & 3 & 5 & 4.37 & 0.52 \\
\hline The company discloses the Environmental reports & 1 & 5 & 4.32 & 0.698 \\
\hline $\begin{array}{l}\text { The company discloses the operational information } \\
\text { such as internal control systems }\end{array}$ & 1 & 5 & 3.99 & 0.747 \\
\hline $\begin{array}{l}\text { The company discloses the company's mission } \\
\text { statement }\end{array}$ & 2 & 5 & 4.34 & 0.751 \\
\hline $\begin{array}{l}\text { The company discloses the organizational } \\
\text { structure/chart }\end{array}$ & 2 & 5 & 4.34 & 0.751 \\
\hline The company discloses the market share analysis & 2 & 5 & 4.42 & 0.715 \\
\hline Mean & & & 4.328 & 0.717 \\
\hline
\end{tabular}


in form of market share analysis had been useful in helping to gauge the sustainability of company activities.

The findings corroborate with those of Healy et al. (1999) who used AIMR disclosure rankings and found that the increases in disclosure level are accompanied by increases in firms' stock returns, institutional ownership, analyst following, and stock liquidity. The findings further agree with those of Leuz and Verrecchia (2000) who studied German firms that have switched from German GAAP to international accounting regime with a greater disclosure requirement (IAS or USGAAP) in consolidated financial statements. Leuz and Verrecchia showed that firms adopting international reporting (more disclosure) were associated with lower bidask spreads and higher trading volume than the ones keeping to the German reporting regime. Coller and Yohn (1997) used a sample of 278 quarterly earnings forecast to investigate whether the manager's decision to issue management earnings forecast reduces information asymmetry. They found that forecasting firms have wider bid ask spreads than a matched sample of nonforecasting firms prior to the forecast release. Espinosa et al. (2005) examined the relationship between disclosure and liquidity using a sample of Spanish listed firms. They found a positive relationship between disclosure and liquidity using Amihud (2002) illiquidity model.

The study sought to identify the extent to which type of auditor affects the quality of financial statements in Nigeria listed firms. The study findings indicated that voluntary disclosure influences the performance of firms as supported by a mean score of 4.198 which implies that the respondents overwhelmingly agreed that the voluntary disclosure had led to higher corporate profitability, market value, increase in successful right issues and bonus issues and increase in capital base. Voluntary disclosure had also improved the competitive edge of the company. Results are presented in Table 3.

The study findings agree with those of Arabmazar and Arzitoon (2008)

Table 2. Investor Decision

\begin{tabular}{lcccc}
\hline Statement & Minimum & Maximum & Mean & $\begin{array}{c}\text { Std. } \\
\text { Deviation }\end{array}$ \\
\hline $\begin{array}{l}\text { Voluntary disclosure in form of Value added } \\
\text { statements has made me to invest more in the } \\
\text { company }\end{array}$ & 1 & 5 & 4.25 & 0.698 \\
$\begin{array}{l}\text { Voluntary disclosure in form of Hr performance } \\
\text { has been useful in helping to gauge the } \\
\text { sustainability of human resources in the company }\end{array}$ & 1 & 5 & 4.06 & 0.855 \\
$\begin{array}{l}\text { Voluntary disclosure in form of CSR reports has } \\
\text { been useful in helping to gauge the sustainability } \\
\text { of company activities }\end{array}$ & 1 & 5 & 4.4 & 0.737 \\
$\begin{array}{l}\text { Voluntary disclosure in form of environmental } \\
\text { reports has been useful in helping to gauge the } \\
\text { sustainability of company activities }\end{array}$ & 2 & 5 & 4.46 & 0.582 \\
$\begin{array}{l}\text { Voluntary disclosure in form of market share } \\
\text { analysis has been useful in helping to gauge the } \\
\text { sustainability of company activities }\end{array}$ & 1 & & & \\
Mean & & 5 & 4.23 & 0.969 \\
\hline
\end{tabular}


Table 3. Performance

\begin{tabular}{|c|c|c|c|c|}
\hline Statement & Minimum & Maximum & Mean & $\begin{array}{c}\text { Std. } \\
\text { Deviation }\end{array}$ \\
\hline $\begin{array}{l}\text { Voluntary disclosure has led to higher corporate } \\
\text { profitability }\end{array}$ & 1 & 5 & 4.18 & 0.962 \\
\hline $\begin{array}{l}\text { Voluntary disclosure has led to increased market } \\
\text { value of the company }\end{array}$ & 1 & 5 & 4.11 & 1.042 \\
\hline $\begin{array}{l}\text { Voluntary disclosure has led to an increase in } \\
\text { successful right issues and bonus issues }\end{array}$ & 1 & 5 & 4.12 & 1.106 \\
\hline $\begin{array}{l}\text { Voluntary disclosure has improved the } \\
\text { competitive edge of the company }\end{array}$ & 1 & 5 & 4.2 & 1.206 \\
\hline $\begin{array}{l}\text { Voluntary disclosure has led to an increase in the } \\
\text { capital base of the company }\end{array}$ & 1 & 5 & 4.38 & 0.586 \\
\hline Mean & & & 4.198 & 0.9804 \\
\hline
\end{tabular}

whoinvestigated the relationship between financial structure characteristics and corporate performance, and the level of information disclosure in the financial statements of the companies. With a sample of 50 companies listed in Tehran Stock Exchange, they came to the conclusion that: There is a significant relationship between financial structure characteristics and adequate disclosure in the financial statements and there is a significant relationship between corporate performance and adequate disclosure in the financial statements.

The study findings further agree with those of Wang et al. (2008) who examined empirically the determinants of voluntary disclosure in the annual reports of Chinese listed firms that issue both domestic and foreign shares. The results indicated that the

Table 4. Regression Model Fitness for Investor Decision

\begin{tabular}{lc}
\hline Indicator & Coefficient \\
\hline $\mathrm{R}$ & 0.333 \\
R Square & 0.111 \\
Std. Error of the Estimate & 0.47264 \\
\hline
\end{tabular}

level of voluntary disclosure is positively related to the proportion of state ownership, foreign ownership, firm performance measured by return on equity, and reputation of the engaged auditor.

\subsection{Inferential Statistics: Overall Model and Hypothesis Testing}

In order to establish the statistical significance of the independent variables on the dependent variable (investor decision) regression analysis was employed. Table 4 shows that the coefficient of determination also called the $\mathrm{R}$ square are $11.1 \%$. This means that the combined effect of the predictor variable (voluntary disclosure) explains $11.1 \%$ of the variations in investor's decisionof listed companies in Nigeria. The correlation coefficient of $33.3 \%$ indicates that the effect of the predictor variable have a weak and positive correlation with investor decision.

Analysis of variance (ANOVA) on Table 5 shows that the effect of voluntary disclosurewas statistically significant in explaining changes in investor decisions in listed companies in Nigeria. This is 
demonstrated by a $\mathrm{p}$ value of 0.000 which is less than the acceptance critical value of 0.05 .

\subsubsection{Hypothesis Testing}

\section{Hypothesis One}

Ho1: There is no significant relationship between voluntary disclosure and investor decision making in Nigeria listed firm.

Table 6 indicates that there was a positive and significant relationship between voluntary disclosure and investor decision making ( $\mathrm{b} 1=0.366, \mathrm{p}$ value, 0.000). This implies that an increase in the effectiveness of voluntary disclosure by 1 unit leads to an increase in investor decisionby 0.366 units. This further implies that voluntary disclosure was statistically significant in explaining investor decision making in listed firms in Nigeria.

\section{Hypothesis Two}

Ho2: There is no significant relationship between voluntary disclosure and firm performance in Nigeria listed firms.
In order to establish the statistical significance of the independent variables on the dependent variable (performance) regression analysis was employed. Table 7 shows that the coefficient of determination also called the $\mathrm{R}$ square are $30.7 \%$. This means that the combined effect of the predictor variable (voluntary disclosure) explains $30.7 \%$ of the variations in performance of listed companies in Nigeria. The correlation coefficient of $55.4 \%$ indicates that the effect of the predictor variable have a strong and positive correlation with investor decision.

Analysis of variance (ANOVA) on Table 8 shows that the effect of voluntary disclosurewas statistically significant in explaining changes in performance of listed companies in Nigeria. This is demonstrated by a $p$ value of 0.000 which is less than the acceptance critical value of 0.05 .

Table 9 indicates that there was a positive and significant relationship between voluntary disclosure and performance (b1 $=0.979, \mathrm{p}$ value, 0.000 ). This implies that an increase in the effectiveness of voluntary disclosure by 1 unit leads to an increase in performance of firms by 0.979 units. This further implies that voluntary disclosure was

Table 5. Analysis of Variance (ANOVA) for Investor Decision

\begin{tabular}{lccccc}
\hline Indicator & Sum of Squares & df & Mean Square & F & Sig. \\
\hline Regression & 3.11 & 1 & 3.11 & 13.923 & 0.000 \\
Residual & 25.019 & 112 & 0.223 & & \\
Total & 28.129 & 113 & & & \\
\hline
\end{tabular}

Table 6. Regression Coefficients for Investor Decision

\begin{tabular}{lcccc}
\hline Variable & B & Std. Error & T & Sig. \\
\hline Constant & 2.695 & 0.427 & 6.316 & 0.000 \\
Voluntary Disclosure & 0.366 & 0.098 & 3.731 & 0.000 \\
\hline
\end{tabular}


statistically significant in explaining performance of listed firms in Nigeria.

\section{CONCLUSION RECOMMENDATIONS}

The findings of this study were crucial in formulating study conclusions. However, the study also took into account the expectations of the study. It was possible to conclude from the study findings that voluntary disclosure was statistically significant in explaining investors' decision and performance of listed companies in Nigeria. It was also possible to conclude that there was high level of voluntary disclosure in Nigeria listed firms which led to high performance of the firms and made it easy for investors to make decision whether to invest in the companies or not.

The result of the study was consistent with the hypothesis of the study on showing that the higher level of disclosure provided in the Nigerian annual reports reduces the spread between bids and asks and thereby increases the stock market liquidity. This result suggests that disclosure is likely to be an important factor in increasing a company's stock market liquidity, supporting the applicability of signaling theory in the context of Arab financial markets. Therefore, it is recommended that Nigerian companies listed at the NSE ought to disclose more information via annual report.

The following recommendations are outlined; this will be useful to stakeholders such as accountants, auditors, company managers, investors, financial analysts, stock brokers and the regulatory bodies responsible for accounting standard setting and stock market regulations.

I. Adequate steps should be taken by the Nigerian Accounting Standards Board

Table 7. Regression Model Fitness for Performance

\begin{tabular}{lc}
\hline Indicator & Coefficient \\
\hline $\mathrm{R}$ & 0.554 \\
$\mathrm{R}$ Square & 0.307 \\
Std. Error of the Estimate & 0.66994 \\
\hline
\end{tabular}

Table 8. Analysis of Variance (ANOVA) for Performance

\begin{tabular}{lccccc}
\hline Indicator & Sum of Squares & Df & Mean Square & F & Sig. \\
\hline Regression & 22.291 & 1 & 22.291 & 49.665 & 0.000 \\
Residual & 50.268 & 112 & 0.449 & & \\
Total & 72.559 & 113 & & & \\
\hline
\end{tabular}

Table 9. Regression Coefficients for Investor Decision

\begin{tabular}{lcccc}
\hline Variable & Beta & Std. Error & T & Sig. \\
\hline Constant & -0.043 & 0.605 & -0.071 & 0.943 \\
Voluntary Disclosure & 0.979 & 0.139 & 7.047 & 0.000 \\
\hline
\end{tabular}


(NASB), Securities Exchange Commission (SEC), Nigerian Stock Exchange (NSE) and other regulatory bodies to ensure full compliance with relevant national accounting disclosure requirements. An increase in the quality of information disclosure will help the users make informed predictions and aid the evaluation of the company's progress which invariably would reinforce the stock market development. Effective enforcement programmes should be put in place to protect the interest of the diverse user groups. Stringent reward/punishment programme should be introduced in order to ensure that all listed companies comply with the mandatory accounting standards in Nigeria.

II. The high compliance of large listed companies can be related to low information costs which could have resulted from the use of modern information technology (IT). The government should encourage smaller companies by promoting the development of IT in Nigeria. Every organization should be able to afford state-of-the-art IT tools. This will reduce information cost and encourage the disclosure of adequate accounting information.

III. The Big four audited $73.4 \%$ of the sampled listed companies and auditor type is quite crucial in explaining disclosure practices. Therefore small audit firms should be encouraged to grow up, through merger or acquisition. With consolidation audit firms can be equipped with the necessary skilled staff, software and hardware that will enable

\title{
УПОТРЕБА ДОБРОВОЉНОГ ОТКРИВАЊА ПОДАТАКА У ОДРЕБИВАҢУ КВАЛИТЕТА ФИНАНСИЈСКИХ ИЗЈАВА: ДОКАЗИ ИЗ НИГЕРИЈСКИХ КОМПАНИЈА
}

\author{
Oyerogba Ezekiel Oluwagbemiga
}

\section{Извод}

Циљ ове студије је да се успостави мерило употребе добровољног откривања код одређивања квалитета финансијских изјава у нигеријским компанијама. Специфично, студија истражује ефекте добровољног откривања на одлуку инвеститора као и перформансе компанија регистрованих у Нигерији. Студија је преузела истраживачки дизајн који је описан као метод сакупљања информација интервјуом или слањем упитника скупу појединаца, који су узорак истраживања.Инструмент сакупљања података за ово истраживање био је упитник, обзиром да су у студији коришћени примарни подаци. Студија је обухватила 258 регистрованих нигеријских компанија. Популација је укључивала рачуновође, екстерне аудиторе и кориснике рачуноводствених података (финансијске аналитичаре, брокере, банкаре, регулаторе и консултанте). Укупан узорак се састојао од 140 особа и коришћено је 20 упитника који су дистрибуирани свакој категорији респондената. За полазну анализу података је коришћена дескриптивна статистика. Мерења и детаљна анализа су потом вршена употребом СПСС 20 софтверског пакета. Резултати студије су показали да постоји велика веза између промењивих, односно једноставнијег доношења одлука о инвестицијама укилико постоји добровољно откривање података у разматраним компанијама. То доводи и до бољих перформанси таквих компанија. Такође, закључено је да постоји висок ниво добровољног откривања података у компанијама регистрованих у Нигерији.

Кључне речи: Добровољно откривање, одлука о инвестицијама, финансијска изјава, перформансе 
them to compete with the Big four firms. Information cost can be reduced, and moreover the audit firms would not have to compromise the level of disclosure out of fear.

\section{References}

Adelopo, I. (2011). Voluntary disclosure practices among listed companies in Nigeria. Advances in Accounting, 27 (2), 338-345.

Adeyemi, S.B. (2006). Impact of Accounting Standards on Financial Reporting in Nigeria, Unpublished PhD. Thesis, University of Lagos.

Ahmed, K. (1996). Disclosure policy choice and corporate characteristics: A study of Bangladesh. Asia-Pacific Journal of Accounting, 3(1), 183- 203.

Ahmed, K. (2005). The impact of nonfinancial company characteristics on mandatory disclosure compliance in developing countries: the case of Bangladesh. International Journal of Accounting, 29, 62-77.

Ali, M.J., Ahmed, K., \& Henry, D. (2004). Disclosure compliance with national accounting standards by listed companies in South Asia. Accounting and Business Research, 34 (3), 183-199.

Amihud, Y. (2002). Illiquidity and stock returns: Cross-section and time-series effects. Journal of Financial Markets, 5 (1), 31-56.

Arabmazar, M. \& Arzitoon R. (2008). The study of the relationship between the financial structure features and functions of corporate and information disclosure level in the financial statements of listed companies in Tehran Stock Exchange. Master's thesis, martyr Beheshti University.

Barako, D.G., Hancock, P., \& Izan, H.Y.
(2006). Factors Influencing voluntary Corporate disclosure by Kenyan companies. Corporate Governance: An International Review, 14 (2), 107-125.

Castillo, E. (2009). Process Optimization: A Statistical Approach, NY: Springer (International Series in Operations Research and Management Science), July 2007. (Reviewed in: Journal of Quality Technology, 40, 2, 2009)

Chow, C.W., \& Wong-Boren, A. (1987). Voluntary financial disclosure by Mexican corporation. The Accounting Review, 62 (3), 533-541.

Cohen, J., Cohen P., West, S.G., \& Aiken, L.S. (2003). Applied multiple regression/correlation analysis for the behavioral sciences. (2nd ed.) Hillsdale, NJ: Lawrence Erlbaum Associates.

Coller, M., \& Yohn, T. (1997). Management forecasts and information asymmetry: An examination of bid-ask spreads. Journal of Accounting Research, 35 (2), 181-191.

Collett, P. \& Hrasky, S. (2005). Voluntary disclosure of corporate governance practices by listed Australian companies. Corporate Governance - An International Review, 13 (2), 188-196.

Daske, H. \& Gebhardt, G. (2006). International financial reporting standards and experts' perceptions of disclosure quality. Abacus 42 (3/4), 461-498.

Dontoh, A. (1989). Voluntary disclosure.Journal of Accounting. Auditing and Finance, 4, 480-511.

Ebiringa, T.O. \& Kule, L. (2014). Offshoring for sustainable value management. Serbian Journal of Management, 9 (1), 105-119.

Espinosa, M., Tapia, M., \& Trombetta, M. (2005). Disclosure and liquidity. Working Paper, University Calos, Madrid. 
Faraway, J.J. (2002). Practical Regression and ANOVA using R.

Gandia, J.L. (2005). Corporate egovernance disclosure in the digital age: an empirical study of Spanish listed companies. Available at SSRN: http://ssrn.com/abstract $=531182$

Ghasim Osmani, M. \& Abbasi, A.R. (2007). The relationship between cost of capital and the level of financial disclosure by listed companies in Tehran Stock Exchange. Master's thesis, martyr Beheshti University.

Grossman, S.J. (1981). The Informational Role of Warranties and Private Disclosure about Product Quality. Journal of Law and Economics, 24 (3), 461-483.

Haniffa, R.M., \& Cooke, T.E. (2002). Culture, corporate governance and disclosure in Malaysian corporations. Abacus, 38 (3), 317-349.

Hassan, O., \& Marston, C. (2010). Disclosure measurement in the empirical accounting literature: a review article. Working paper, Economics and Finance.Brunel University.

Healy, P.M., \& Palepu, K.G. (2001). Information asymmetry, corporate disclosure, and the capital markets: A review of the empirical disclosure literature. Journal of Accounting and Economics, 31, 405-440.

Healy, P.M., Hutton, A.P., \& Palepu, K.G. (1999). Stock performance and intermediation changes surrounding sustained increases in disclosure. Contemporary Accounting Research, 16 (3), 485-520.

Heflin, F., Shaw, K.W., \& Wild, J.J. (2002). Disclosure quality and market liquidity. Working Paper, Robert H. Smith School of Business, College Park, MD.

Holthausen, R.W., \& Leftwich, R. W. (1983). The economics consequences of accounting choice. Journal of Accounting and Economics, 5, 77-177.

Hossain, M., Perera, M.H.B., \& Rahman, A.R. (1995). Voluntary disclosure in the annual reports of New Zealand companies. Journal of International Financial Management \& Accounting, 6 (1), 69-87.

Hossain, M., Tan, L., \& Adams, M. (1994). Voluntary disclosure in an emerging capital market: Some empirical evidence from companies listed on the Kuala Lumpur stock exchange. International Journal of Accounting, 29 (4), 334-351.

Iatridis, G. (2008). Accounting disclosure and firms' financial attributes: Evidence from the UK stock market. International Review of Financial Analysis, 17, 219-241.

Inchausti, A.G. (1997). The influence of company characteristics and accounting regulation on information disclosed by Spanish firms. European Accounting Review, 6 (1), 45-68.

Jensen, M., \& Meckling, W.H. (1976). Theory of the firm: Managerial behavior, agency costs, and ownership structure. Journal of Financial Economics, 3 (3), 305-360.

Lang, M., \& Lundholm, R. (2000). Voluntary disclosure and equity offerings: reducing information asymmetry or hyping the stock? Contemporary Accounting Research, 17 (4), 623- 662.

Leuz, C., and Verrecchia, R.E. (2000). The economic consequences of increased disclosure. Journal of Accounting Research, 38 (3), 91-124.

Malone, D., Fries, C., \& Jones, T. (1993). An empirical investigation of the extent of corporate financial disclosure in the oil and gas industry. Journal of Accounting. Auditing and Finance, 8 (3), 249-273.

Milgrom, P.R. (1981). Good News and Bad News: Representation Theorems and 
Applications. The Bell Journal of Economics, 32, 97-180.

Economics, 12 (2), 380-391.

Naser, K., Alkhatib, K., \& Karbari, Y. (2002). Empirical evidence on the depth of corporate information disclosure in developing countries: The case of Jordan. International Journal of Commerce and Management, 12 (3/4), 122-134.

Ofoegbu, G., \& Okoye, E. (2006). The relevance of accounting and auditing Standards in corporate financial reporting in Nigeria: Emphasis on compliance. The Nigerian Accountant, 39 (4), 45-53.

Okike, E.N.M. (2000). Extension of information in accounting reports: An investigation. Nigerian Financial Review, 3 (2).

Osisioma, B.C. (2001). Fine tuning corporate reporting task for accountants, The Certified National Accountants, 9 (2), 40-55.

Pahuja, S. (2009). Relationship between environmental disclosures and corporate characteristics: a study of large manufacturing companies in India. Social Responsibility Journal, 5 (2), 227-244.

Suwaidan, M., Al-Omari, A., \& Haddad, R., (2004). Social Responsibility Disclosure and Corporate Characteristics: the Case of Jordanian Industrial Compaines, International Journal of Accounting, Auditing and Performance Evaluation, 1(4), 432-447.

Uyar, A. (2011). Firm Characteristics and Voluntary Disclosure of Graphs in Annual Reports of Turkish Listed Companies. African Journal of Business Management, 5 (17), 7651-7657.

Verrecchia, R.E. (1983). Discretionary disclosure. Journal of Accounting and Economics, 5, 365-380.

Verrecchia, R.E. (2001). Essays on disclosure. Journal of Accounting and
Wallace, R.S.O. (1988). Corporate financial reporting in Nigeria. Accounting and Business Research, 18 (72), 352-362.

Wang, K., Sewon, C., \& Claiborne, M.C. (2008). Determinants and consequences of voluntary disclosure in an emerging market: Evidence from China. Journal of International Accounting, Auditing and Taxation, 17(1), 14-30.

Watts, R., \& Zimmerman, J. (1986). Prentice-Hall, Englewood Cliffs,NJ: Positive Accounting Theory.

World Bank (2004). Report on the Observance of Standards and Codes (ROSC) Nigeria, Accounting and Auditing. Retrieved March 13, 2014, from http://www.worldbank.org/ifa/rosc_aa_nga.p df.

Zhang, L., \& Ding, S. (2006). The effect of increased disclosure on cost of equity capital: Evidence from China. Review of Quantitative Finance and Accounting, 27 (4), 383-401. 